\title{
Penerapan Sistem Pakar Untuk Diagnosa Penyakit Kucing Pada Aplikasi Berbasis Android Dengan Metode Forward Chaining
}

\author{
Baiq Andriska Candra Permana ${ }^{*}$, Muhammad Djamaluddin ${ }^{2}$, Muhamad Afandi ${ }^{3}$, Hariman Bahtiar ${ }^{4}$ \\ 1,2,3 Program Studi Teknik Informatika, Universitas Hamzanwadi \\ ${ }_{4}^{4}$ Program Studi Sistem Informasi , Universitas Hamzanwadi \\ andriska.cp@gmail.com
}

\begin{abstract}
Abstrak
Perkembangan teknologi dapat digunakan diberbagai sektor kehidupan salah satunya pemafaatan android pada sistem pakar. Sistem pakar dapat menggantikan peran seorang pakar dimana pengguna bisa mendapatkan informasi atau solusi atas suatu permasalahan tanpa harus bertemu langsung dengan sorang pakar. Pemanfaatan sistem pakar diantaranya adalah untuk mendiagnosa awal penyakit pada hewan. Kucing merupakan hewan lucu dan menggemaskan yang umum dipelihara oleh masyarakat. Namun kucing sering kali terkena penyakit baik yang disebabkan oleh virus, bakteri maupun parasit. Sangat penting bagi para pemelihara kucing untuk mengetahui penyakit yang diderita oleh kucing secara dini . Penggunaan metode forward chaining yang diterapkan pada sisstem pakar penyakit kucing berbasis android dapat dimanfaatkan oleh para pemelihara kucing untuk mendeteksi dini penyakit pada kucing, dan dengan aplikasi ini pemilik dapat menghemat biaya waktu dan tenaga karena mendapatkan informasi penyakit kucing lebih cepat tanpa harus bertemu langsung dengan pakar.
\end{abstract}

Kata Kunci : Aplikasi Mobile, Forward Chaining, Sistem Pakar.

\begin{abstract}
Technological advances can be used in various sectors of life, one of the benefits of this technology is the use of android in expert systems. Expert systems can replace the role of an expert where users can get information or solutions to a problem without having to meet directly with an expert. One of the several uses of expert systems is to diagnose disease in animals early. Cats are cute and adorable animals that are commonly kept by many people. However, cats are often affected by diseases caused by viruses, bacteria or parasites. It is very important for cat owners to find out the disease suffered by the cat early. The use of the forward chaining method applied to an android-based cat disease expert system can be used by cat keepers to detect disease in cats early, and with this application owners can save time and energy costs because they get cat disease information faster without having to meet directly with experts.
\end{abstract}

Keyword : Mobile Apps, Forward Chaining, Expert System.

\section{Pendahuluan}

Dengan kemajuan dan perkembangan teknologi yang terus berkembang pesat dari waktu kewaktu segala bentuk kegiatan yang dilakukan oleh manusia tidak lepas dari penggunaan teknologi. Berbagai bentuk kebutuhan hidup yang sehari - hari dipergunakan manusia banyak terbantu oleh keberadaan teknologi salah satunya dengan pemanfaatan sistem pakar expert system)[1][2][3]. 
Sistem pakar merupakan suatu bentuk program komputer atau sistem informasi dimana sistem ini ditujukan untuk membantu didalam mengambil suatu keputusan secara spesifik untuk memecahkan permasalahan yang dianggap cukup rumit. Sistem ini menyimpan informasi yang didapatkan dari pakar akan tetapi fungsinya tidak sepenuhnya dapat menggantikan kemampuan seorang pakar tapi sistem ini dapat mewakili kemampuan seorang pakar [4].

Salah satu bentuk penerapan sistem pakar adalah untuk mendiagnosa awal penyakit hewan serperti kucing. Kucing merupakan hewan yang menjadi perhatian karena kucing dianggap memiliki daya tarik sendiri karena memiliki warna bulu dan warna mata yang beraneka ragam dan kucing merupakan hewan peliharaan yang sangat umum dimiliki dimasyarakat [5][6].

Walaupun kucing merupakan hewan peliharaan yang relative mudah untuk dirawat akan tetapi tidak menutup kemungkinan terkadang kucing peliharaan terjangkit penyakit yang disebabkan baik oleh virus, bakteri maupun parasit. Kendala yang banyak terjadi adalah karena lokasi dokter hewan tidak selalu tersedia diberbagai tempat terutama sekali yang jauh dari perkotaan.

Oleh sebab itu diperlukan suatu teknologi yang dapat digunakan untuk mendeteksi dini penyakit kucing berdasarkan gejala - gejala yang tampak dengan memanfaatkan smartphone yang dimiliki, sehingga para pemilik kucing dapat mengambil tindakan terhadap kucing peliharaan saat terjangkit suatu penyakit.

\section{Tinjauan Pustaka}

\subsection{Penelitian Terkait}

Penelitian yang dilakukan Siti Nurazizah dan Maulana S pada 2018 yaitu membangun suatu aplikasi berbasis android untuk mendeteksi penyakit kulit pada kucing disertai dengan tindakan lanjutan ketika penyakit kulit pada kucing sudah ditemukan. Sistem paar yamng dibangun menerapkan metode forward chaining dan tingkat akurasi sistem pakar yang dibangun adalah $67 \%$ setelah diujicoba pada 30 orang tenaga medis [7].

Penelitian oleh Brigita dkk, tahun 2020 yaitu membuat sistem pakar untuk diagnose penyakit ayam pedaging dengan menggunakan metode forward chaining. Hasil yang diperoleh adalah adanya aplikasi berbasis web yang dapat dimanfaatkan oleh para peternak ayam untuk mengenali penyakit pada ayam pedaging sekaligus cara untuk menangani penyakit tersebut [8].

Penelitian oleh yulyanto tahun 2019 yaitu membuat sistem pakar berbasis android untuk mendiagnosa penyakit pada sapi. Sistem pakar ini dibangun dalam upaya menurunkan resiko tingginya kerugian yang dialami peternak karena adanya penyakit reproduksi pada sapi yang tidak ditangani secara dini. Metode yang digunakan 
pada sistem pakar ini adalah Tsukamoto Fuzzy dengan menggunakan enam gejala klinis pada sapi. Hasil pengujian pada sistem yang dibangun berhasil menunjukan tingkat resiko sapi terjangkit penyakit sistem reproduksi [9].

\subsection{Landrasan Teori}

\section{Konsep Sistem Pakar}

Sisterm Pakar merupakan cabang dari Artificial Intelligence ( $\mathrm{Al}$ ) dimana sistem pakar merupakan sistem komputer yang dapat memecahkan suatu permasalahan yang rumit selayaknya yang dapat dilakukan oleh seorang pakar namun tidak sepenuhnya dapat menggantikan peran seorang pakar [10][3]. Sistem pakar terbentuk atas dua bagian utama yaitu sistem pengembang dan sistem konsultasi yang dapat digambarkan pada gambar 1 :

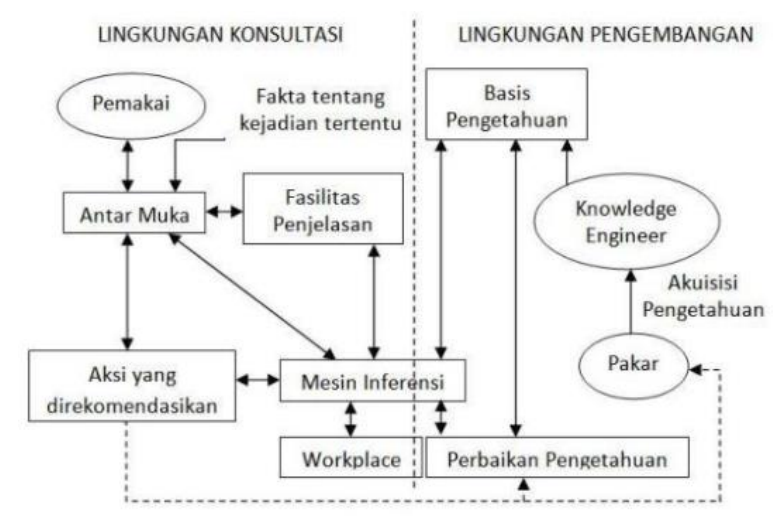

Gambar 1. Arsitektur Sistem Pakar

\section{Metode Forward Chaining}

Metode forward chaining bekerja dengan teknik reasoning ( pemikiran ) dimana mesin bekerja mengambil suatu keputusan dengan cara yang logis [11][12][13]. Makanisme kerjanya dengan melakukan pencocokan terhadap fakta yang ada kemudian menarik kesimpulan dengan dimulai dari pencocokan fakta menggunakan kondisi (IF) terlebih dahulu menggunakan aturan (IF THEN) [3][14]. Ilustrasi metode forward chaining ditunjukan oleh gambar 2 :

\begin{tabular}{|c|c|c|c|}
\hline Data & Aturan & $\rightarrow$ & Kesimpulan \\
\hline $\begin{array}{l}A=1 \\
B=2\end{array}$ & $\begin{array}{c}\text { Jika } A=1 \text { Dan } B=2 \\
\text { MAKA C=3 } \\
\text { Jika } C=3 \text { MAKA } D=4\end{array}$ & & $D=4$ \\
\hline
\end{tabular}

Gambar 2. Ilustrasi Metode Forward Chaining

\section{Kucing Dan Penyakit Pada Kucing}

Kucing merupakan salah satu peliharaan paling popular di serulurh dunia, paling tidak sejak tahun 4000 SM. Beberapa penyakit yang sering dialami oleh kucing diantaranya [15] [5]:
a. Flu kucing
b. Cacingan
C. Scabies
d. Jamur Cryptococus
e. Flea atau
f. Feline leukemia

\section{Metode Penelitian}

.Beberapa tahapan yang dilakukan pada penelitian ini ditunjukan oleh gambar 3 : 


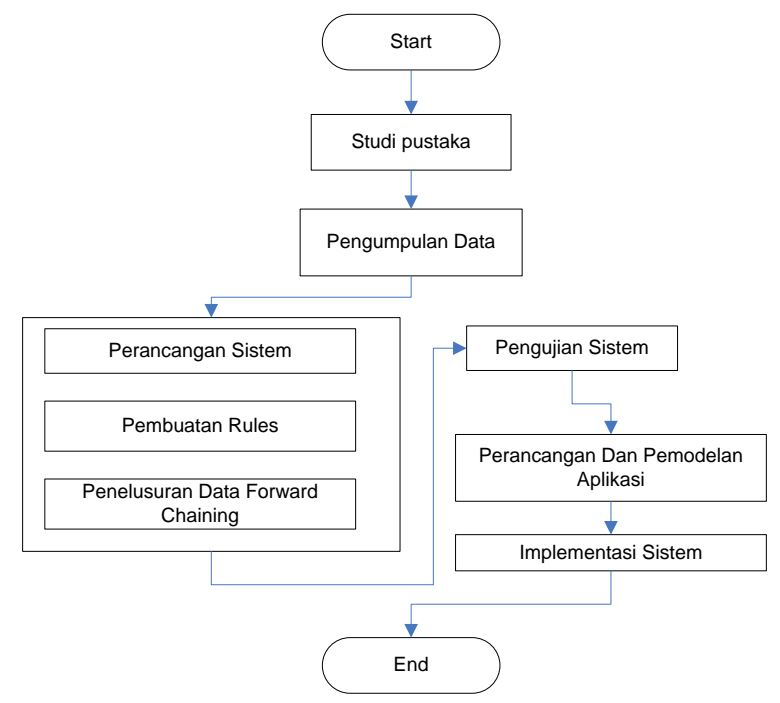

Gambar 3. Tahap Pegembangan Sistem

Penelitian yang dilakukan berlokasi di Bruno Pet Shop , Jl. Prop M Yamin No 81 Selong Kabupaten Lombok Timur NTB. Penelitian ini di mulai dari bulan April 2021.

\subsection{Pembuatan Rules}

Sebelum membangun suatu aplikasi sistem pakar terlebih dahulu diperlukan pembuatan rules pangetahuan. Data penyakit pada kucing ditunjukan oleh tabel 1 :

Tabel 1. Data Penyakit Kucing

\begin{tabular}{|l|l|}
\hline Kode penyakit & Nama Penyakit \\
\hline P1 & Scabies \\
\hline P2 & Otitis \\
\hline P3 & Cacingan \\
\hline P4 & Ringworm \\
\hline P5 & Rabies \\
\hline
\end{tabular}

Berbagai gejala terhadap penyakit kucing ditunjukan pada tabel 2 berikut :

\begin{tabular}{|l|l|}
\hline Kode & \multicolumn{1}{|c|}{ Gejala } \\
\hline G1 & Bulu rontok hingga botak \\
\hline G2 & Kerak disekitar telinga \\
\hline G3 & Kulit Bersisi \\
\hline G4 & Gatal disekitar telinga \\
\hline G5 & Sering menggelengkan kepala \\
\hline G6 & Menggaruk telinga hingga luka \\
\hline G7 & Cairan ditelinga berbau tak sedap \\
\hline G8 & Kepala miring tidak bisa berjalan lurus \\
\hline G9 & Kurus tapi perut buncit \\
\hline G10 & Diare \\
\hline G11 & $\begin{array}{l}\text { Ada cacing pada kotoran atau saat } \\
\text { muntah }\end{array}$ \\
\hline G12 & Kebotakan berbentuk lingkaran \\
\hline G13 & Sering menggaruk badan \\
\hline G14 & Agresif \\
\hline G15 & Sensitif \\
\hline G16 & Tidak nafsu makan \\
\hline G17 & Gelisah \\
\hline G18 & Badan lemah \\
\hline
\end{tabular}

Berdasarkan tabel gejala dan penakit didapatkan rule base pengetahuan yang ditunjukan oleh tabel 3:

Tabel 3. Rule Base

\begin{tabular}{|l|l|}
\hline No & Rule Base \\
\hline 1 & $\begin{array}{l}\text { IF G1 AND G2 AND G3 AND G4 THEN } \\
\text { P1 }\end{array}$ \\
\hline 2 & $\begin{array}{l}\text { IF G5 AND G6 AND G7 AND G8 THEN } \\
\text { P2 }\end{array}$ \\
\hline 3 & $\begin{array}{l}\text { IF G9 AND G10 AND G11 AND G12 } \\
\text { AND G17 AND G19 THEN P3 }\end{array}$ \\
\hline 4 & IF G1 AND G13 AND G14 THEN P4 \\
\hline 5 & $\begin{array}{l}\text { IF G15 AND G16 AND G18 AND G19 } \\
\text { THEN P5 }\end{array}$ \\
\hline
\end{tabular}




\section{Hasil dan Pembahasan}

Berikut adalah tampilan antarmuka aplikasi diagnose penyakit kucing berbasis android yang berhasil dibangun sebagai tampilan utama saat mesuk ke aplikasi penyakit kucing :

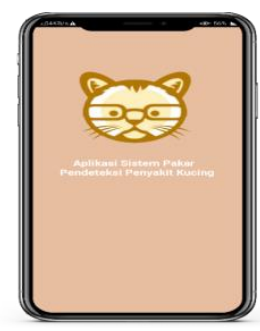

Gambar 4. Halaman splash Screen

Halaman selanjutnya adalah halaman antarmuka utama ditunjukan oleh gambar 5 :
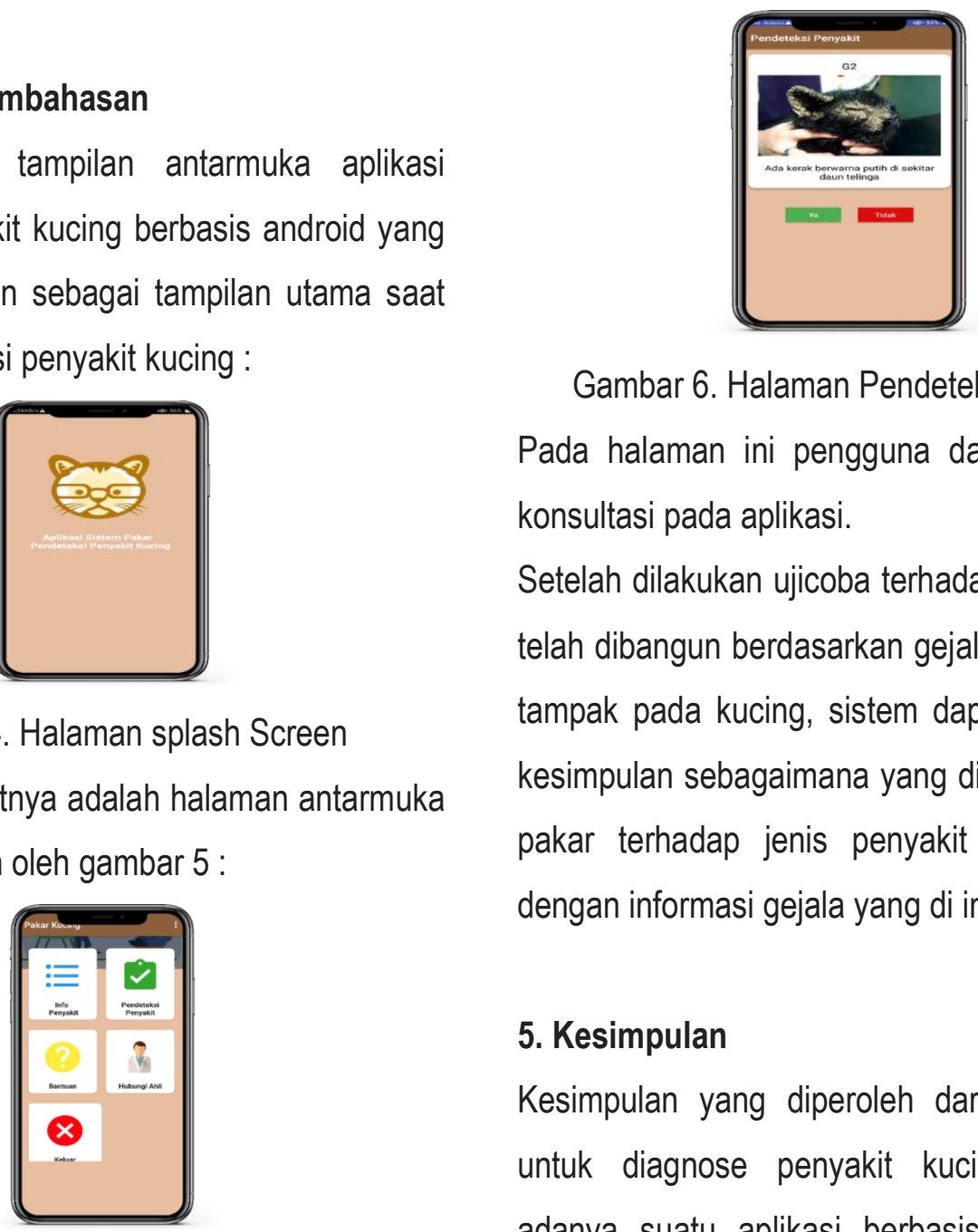

Gambar 6. Halaman Pendeteksi Penyakit Pada halaman ini pengguna dapat melakukan konsultasi pada aplikasi.

Setelah dilakukan ujicoba terhadap aplikasi yang telah dibangun berdasarkan gejala - gejala yang tampak pada kucing, sistem dapat memberikan kesimpulan sebagaimana yang dilakukan sorang pakar terhadap jenis penyakit kucing sesuai dengan informasi gejala yang di inputkan.

\section{Kesimpulan}

Kesimpulan yang diperoleh dari sistem pakar untuk diagnose penyakit kucing ini adalah adanya suatu aplikasi berbasis android yang

Gambar 5. Halaman menu utama

Pada halaman ini terdapat beberapa menu yang dapat dipilih oleh pengguna, diantaranya konsultasi melalui aplikasi, kemudian deskripsi tentang kucing dan penyakitnya serta terdapat menu untuk berhubungan langsung dengan pakar.

Tampilan halaman konsultasi ditunjukan oleh gambar 6 : dapat dimanfaatkan oleh para pemelihara kucing untuk dapat mendeteksi secara dini penyakit yang diderita oleh kucing dengan melihat gejala - gejala yang tampak pada kucing. Sistem dapat digunakan dimanapun dan kapanpun hanya saja untuk bisa berkonsultsi langsung dengan pakar pengguna harus terhubung langsung dengan internet. 


\section{Daftar Pustaka}

[1] N. Amalia and D. Hidayatullah, "Sistem pakar diagnosa penyakit kucing dengan metode dempster shafer berbasis web," J. TIKomSiN, vol. 4, no. 2, 2019.

[2] C. F. Tan, L. S. Wahidin, S. N. Khalil, N. Tamaldin, J. Hu, and G. W. M. Rauterberg, "The application of expert system: A review of research and applications," ARPN J. Eng. Appl. Sci., vol. 11, no. 4, pp. 2448-2453, 2016.

[3] N. Nurhidayati, A. Sudianto, and S. Suhartini, "Sistem Pakar Berbasis Web Untuk Diagnosa Hama Dan Penyakit Jamur Tiram Pada Kelompok Tani Desa Dasan Borok Kabupaten Lombok Timur," Infotek J. Inform. dan Teknol., vol. 3, no. 2, pp. 131-139, 2020, doi: 10.29408/jit.v3i2.2316.

[4] R. Ridwansyah, J. J. Purnama, H. Hermanto, S. Suhardjono, and A. Hamid, "Aplikasi Mobile Sistem Pakar Dalam Mengidentifiaksi Diagnosis Penyakit Kucing," INFORMATICS Educ. Prof. J. Informatics, vol. 5, no. 1, p. 23, 2020, doi: 10.51211/itbi.v5i1.1414.

[5] Y. Pandu Buana and D. Destiani Siti Fatimah, "Pengembangan Sistem Pakar Diagnosis Penyakit Kucing," J. Algoritm., vol. 12, no. 2, pp. 596-601, 2016, doi: 10.33364/algoritma/v.12-2.596.

[6] T. Informatika, "CURTINA: Computer Science or Informatic Journal Volume 2 No 1 Juli 2021 SISTEM PAKAR DIAGNOSA PENYAKIT KUCING DENGAN NAÏVE BAYES Dany Meiko Bangkit Setyawan*, Andy Haryoko*, Alfian Nurlifa*, Andik Adi Suryanto*.," vol. 2, no. 1, pp. 37-46, 2021.

[7] H. S. Arfajsyah, I. Permana, and F. N. Salisah, "Sistem Pakar Berbasis Android Untuk Diagnosa Penyakit Gigi Dan Mulut," J. IIm. Rekayasa dan Manaj. Sist. Inf., vol. 4, no. 2, p. 110, 2018, doi: 10.24014/rmsi.v4i2.5678.

[8] D. Yulianto, I. Idris, I. Wasiso, and K.
Kusrini, "Implementasi Metode Certainty Factors Pada Sistem Pakar Diagnosis Penyakit Ayam Berbasis Web," J. Comput. Inf. Syst. Technol. Manag., vol. 3, no. 1, pp. 16-23, 2020

[9] Y. M.Kom, "Sistem Pakar Diagnosa Penyakit pada Sapi Berbasis Android," Nuansa Inform., vol. 13, no. 1, 2019, doi: 10.25134/nuansa.v13i1.1645.

[10] M. Silmi, E. A. Sarwoko, and F. Chaining, "SISTEM PAKAR BERBASIS WEB DAN MOBILE WEB UNTUK MENDIAGNOSIS PENYAKIT DARAH PADA MANUSIA DENGAN MENGGUNAKAN METODE INFERENSI FORWARD CHAINING Muhammad," vol. 4, pp. 31-38, 1960.

[11] S. Rofiqoh, D. Kurniadi, and A. Riansyah, "Sistem Pakar Diagnosa Penyakit Pada Tanaman Karet Menggunakan Metode Forward Chaining," Ranc. Bangun e-CRM pada Pasar Murah Solo, vol. 1, no. 1, pp. 54-60, 2020.

[12] A. Muhammad Saiful, "Sistem Pakar Diagnosa Penyakit Pencernaan dan Solusi Penanganan dengan metode Forward Chaining Berbasis Web," Akrab Juara, vol. 5, no. 1, pp. 43-54, 2020,

[13] R. Oktapiani, "Penerapan Metode Forward Chaining Pada Sistem Pakar Kerusakan Komputer," IJCIT (Indonesian J. Comput. Inf. Technol., vol. 02, no. 02, pp. 14-23, 2017.

[14] R. E. Putri, K. M. Morita, and Y. Yusman, "Penerapan Metode Forward Chaining Pada Sistem Pakar Untuk Mengetahui Kepribadian Seseorang," J. Inf. Technol. Comput. Sci., vol. 3, no. 1, pp. 60-66, 2020.

[15] O. Nurdiawan and L. Pangestu, "Penerapan Sistem Pakar dalam Upaya Meminimalisir Resiko Penularan Penyakit Kucing," InfoTekJar (Jurnal Nas. Inform. dan Teknol. Jaringan), vol. 3, no. 1, pp. 65-73, 2018, doi: 10.30743/infotekjar.v3i1.532. 